\title{
Development of the Community Health Improvement Navigator Database of Interventions
}
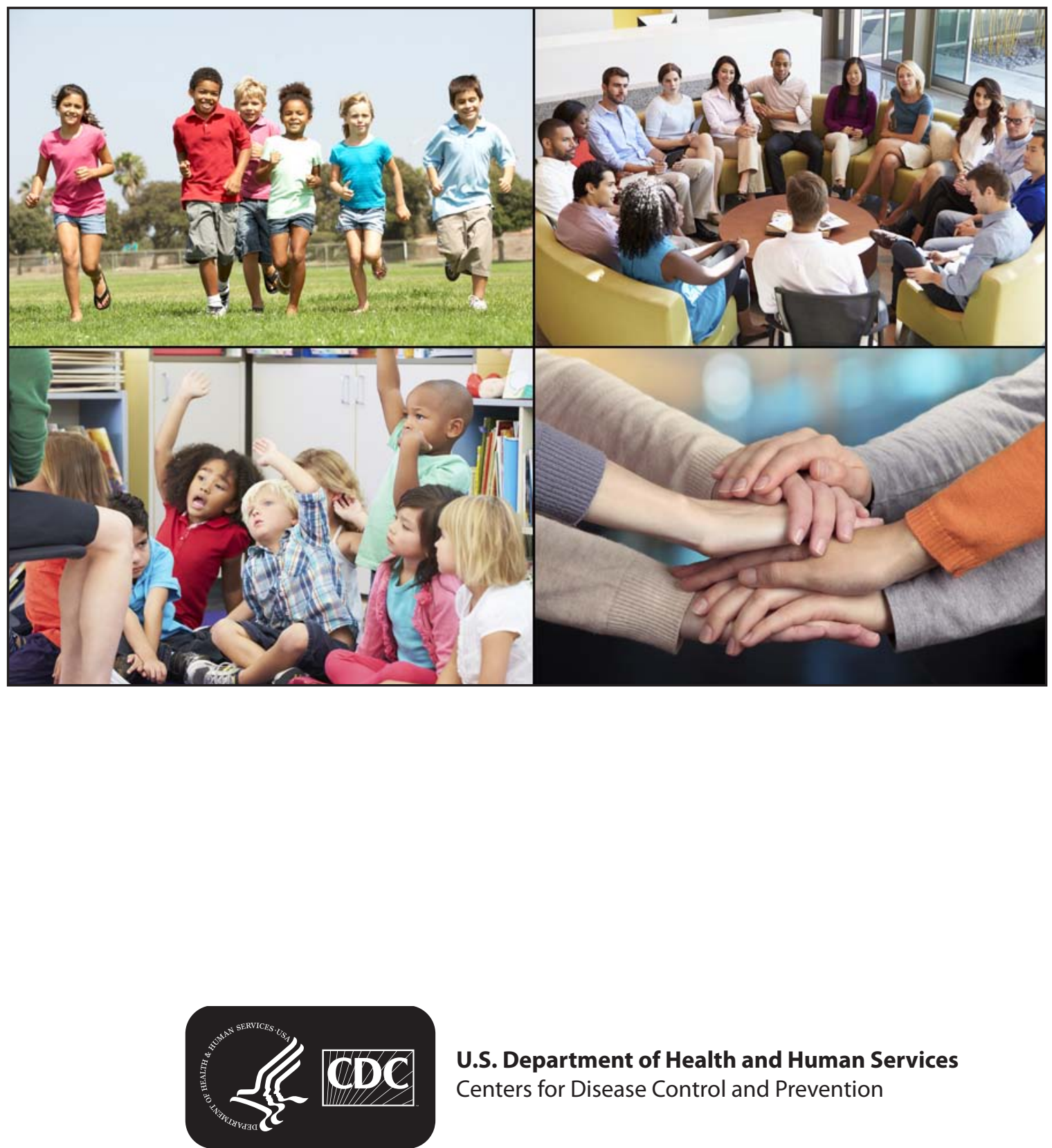


\section{CONTENTS}

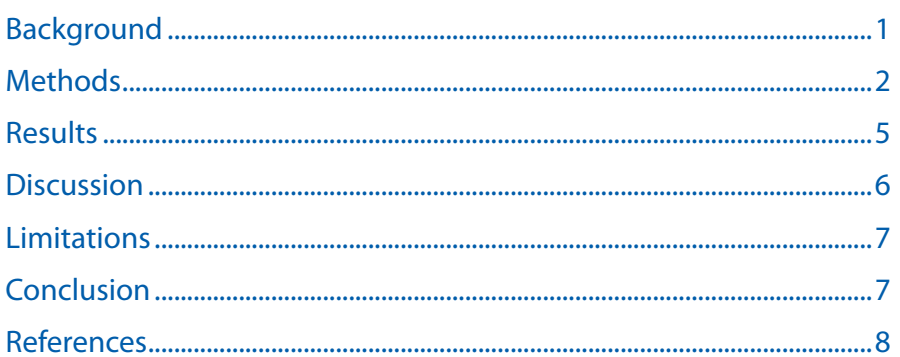

The MMWR series of publications is published by the Center for Surveillance, Epidemiology, and Laboratory Services, Centers for Disease Control and Prevention (CDC), U.S. Department of Health and Human Services, Atlanta, GA 30329-4027.

Suggested citation: [Author names; first three, then et al., if more than six.] [Title]. MMWR Suppl 2016;65(Suppl-\#):[inclusive page numbers].

\section{Centers for Disease Control and Prevention}

Thomas R. Frieden, MD, MPH, Director

Harold W. Jaffe, MD, MA, Associate Director for Science

Joanne Cono, MD, ScM, Director, Office of Science Quality

Chesley L. Richards, MD, MPH, Deputy Director for Public Health Scientific Services

Michael F. Iademarco, MD, MPH, Director, Center for Surveillance, Epidemiology, and Laboratory Services

\section{MMWR Editorial and Production Staff (Serials)}

Sonja A. Rasmussen, MD, MS, Editor-in-Chief

Charlotte K. Kent, PhD, MPH, Executive Editor

Christine G. Casey, MD, Editor

Teresa F. Rutledge, Managing Editor

David C. Johnson, Lead Technical Writer-Editor

Catherine B. Lansdowne, MS, Project Editor

Timothy F. Jones, MD, Chairman Matthew L. Boulton, MD, MPH

Virginia A. Caine, MD

Katherine Lyon Daniel, PhD

Jonathan E. Fielding, MD, MPH, MBA

David W. Fleming, MD

Martha F. Boyd, Lead Visual Information Specialist Maureen A. Leahy, Julia C. Martinroe, Stephen R. Spriggs, Moua Yang, Tong Yang, Visual Information Specialists

Quang M. Doan, MBA, Phyllis H. King, Teresa C. Moreland, Terraye M. Starr, Information Technology Specialists

\section{MMWR Editorial Board}

William E. Halperin, MD, DrPH, MPH

King K. Holmes, MD, PhD

Robin Ikeda, MD, MPH

Rima F. Khabbaz, MD

Phyllis Meadows, $\mathrm{PhD}, \mathrm{MSN}, \mathrm{RN}$

Jewel Mullen, MD, MPH, MPA
Jeff Niederdeppe, $\mathrm{PhD}$

Patricia Quinlisk, MD, MPH

Patrick L. Remington, MD, MPH

Carlos Roig, MS, MA

William L. Roper, MD, MPH

William Schaffner, MD 


\title{
Development of the Community Health Improvement Navigator Database of Interventions
}

\author{
Brita Roy, $\mathrm{MD}^{1}$ \\ Joel Stanojevich, $\mathrm{MPH}^{2}$ \\ Paul Stange, $\mathrm{MPH}^{3}$ \\ Nafisa Jiwani, $\mathrm{MPH}^{3}$ \\ Raymond King, $\mathrm{PhD}^{4}$ \\ Denise Koo, $\mathrm{MD}^{3}$ \\ ${ }^{1}$ Yale University School of Medicine, New Haven, Connecticut \\ ${ }^{2}$ Center for Global Health, CDC, Atlanta, Georgia \\ ${ }^{3}$ Office of Associate Director for Policy, CDC, Atlanta, Georgia \\ ${ }^{4}$ National Center for Chronic Disease Prevention and Health Promotion, CDC, Atlanta, Georgia
}

Corresponding author: Brita Roy, MD, Department of Internal Medicine, Yale University School of Medicine. Telephone: 203-785-5564; E-mail: brita.roy@yale.edu.

\section{Summary}

With the passage of the Patient Protection and Affordable Care Act, the requirements for hospitals to achieve tax-exempt status include performing a triennial community health needs assessment and developing a plan to address identified needs. To address community health needs, multisector collaborative efforts to improve both health care and non-health care determinants of health outcomes have been the most effective and sustainable. In 2015, CDC released the Community Health Improvement Navigator to facilitate the development of these efforts. This report describes the development of the database of interventions included in the Community Health Improvement Navigator. The database of interventions allows the user to easily search for multisector, collaborative, evidence-based interventions to address the underlying causes of the greatest morbidity and mortality in the United States: tobacco use and exposure, physical inactivity, unhealthy diet, high cholesterol, high blood pressure, diabetes, and obesity.

\section{Background}

Population-level health outcomes in the United States, including life expectancy and infant mortality rates, lag behind those of other countries in the Organisation for Economic Co-operation and Development, despite spending the greatest percentage of its gross domestic product on health care (1-5). To attenuate this gap, health care payment models are shifting away from rewarding volume of service and toward rewarding value based on health outcomes $(6,7)$. However, focusing on clinical improvements alone is unlikely to substantially improve population health outcomes (8). During the 20th century, most causes of and contributing factors to morbidity and mortality within the United States shifted from infectious to chronic (9). The underlying causes of these chronic illnesses are associated with complex social, behavioral, and environmental factors (10).

Various models describe the determinants of health outcomes, each emphasizing the relative contribution of health care and other factors (e.g., health behaviors and socioeconomic factors) to health outcomes and the interdependence of these factors $(10-15)$. These models indicate that health care accounts for $10 \%-20 \%$ of health outcomes, whereas socioeconomic factors account for up to $40 \%$ (11). This underscores the importance of collaboration between health systems and non-health care sectors to prevent disease and improve community health outcomes (16-21). Non-health care partners might include public health, businesses, the local government, community members, and community-based organizations. These sectors can work together with health systems to create sustained changes that address the root causes of disease, including socioeconomic factors, the physical environment, health behaviors, and clinical care (22). Simultaneous interventions in multiple areas, both within and outside the health care system, have the greatest sustained improvements in community and population health (http://www.cdc.gov/chinav/docs/chi_ nav_infographic.pdf). For example, in Maine, collaboration among health systems, the public health field, and multiple community organizations resulted in a multicomponent strategy to improve and maintain control of cardiovascular risk factors for hypertension, hyperlipidemia, and tobacco use over a 40-year period (23).

Policies in the United States are beginning to reinforce these findings. To be eligible for tax-exempt status, also known as 501(c)(3) status, hospitals must meet requirements established by the Internal Revenue Service (IRS). Before passage of Patient Protection and Affordable Care Act (ACA) in March 2010, many hospitals met the IRS requirements for tax-exempt status through increasing access to medical care to those without insurance or by making clinical care for indigent patients more efficient (24). 
Although beneficial, these efforts did not address the root causes of disease. For example, although a tax-exempt hospital might have provided free diabetes medications and medical care for diabetic patients without insurance, if the hospital did not also address the underlying causes of type 2 diabetes (e.g., access to healthy foods and safe locations for physical activity), diabetesrelated outcomes among these patients might not have improved substantially or might have worsened.

There are new requirements for nonprofit hospitals to maintain their tax-exempt status. With the passage of ACA regulations, tax-exempt hospitals are provided incentives to create and sustain multisector collaborations to address underlying causes of disease. Every 3 years, tax-exempt hospitals must conduct a community health needs assessment and develop an implementation plan to address identified needs. These needs assessments are required to solicit input from government public health officials (25). In addition, the ACA regulation allows for joint implementation strategies and input from other community members, including health care consumers and advocates, community-based organizations, academic experts, school districts, health care providers, and neighboring hospitals. The regulation requires a description of the community health needs assessment process, communities served by the organization, and how the activities promote the health of the communities served by the organization. Such collaborative interventions have the added benefit of better preparing hospitals for imminent value-based payment models (26), and, most importantly, for improving the overall health of their communities.

To ensure short- and long-term success, IRS allows hospital administrators and their partners to seek multisector, collaborative, evidence-based interventions to address the priority health needs identified in their communities $(18,27)$. For example, to reduce rates of childhood obesity in a community, a hospital and its community partners might benefit from finding ways to coach families about healthy eating, increase access to healthy foods, and create safe places to walk and play. Accordingly, in addition to increasing time available for clinicians to counsel families on the importance of healthy food choices and preparation, partnerships might include collaboration with school superintendents and local grocers or farmers markets to increase children's access to fresh fruits and vegetables in school meals and through school gardens. Another partnership could involve the US Department of Transportation creating safe places to walk by building sidewalks and enlisting crossing guards to increase the feasibility and safety of walking school-bus programs, programs in which adults walk students to school along a specific route (28-30). Together, changes such as these are likely to have a substantial, long-lasting impact in the community and reduce future health care costs $(10,18,27)$.

No easily accessible, comprehensive inventory exists that is designed for hospitals to identify effective evidence-based multisector strategies to improve community health. This report describes an online tool intended to support this type of collaboration: the CDC Community Health Improvement Navigator (CHI Navigator). The CHI Navigator provides resources that describe the necessity of collaborative approaches to improve community health, offers tools reviewed by experts to establish and maintain effective collaborations, and assists users in finding effective interventions to improve community health and well-being. This report focuses on the development of a critical component of the CHI Navigator: the database of evidence-based interventions (available at http://www. cdc.gov/CHInav). The conceptual framework and methods used in the development of the database of interventions are described in detail. Hospital administrators can use the $\mathrm{CHI}$ Navigator's database of interventions to select and implement evidence-based interventions that have been effective in similar communities with similar collaborators to develop plans to address problems identified in the triennial community health needs assessment, in alignment with the IRS requirements for tax-exempt status.

\section{Methods}

In 2015, CDC released the CHI Navigator, a freely available website that supports hospitals, public health, and other community stakeholders in their work to improve the health of their communities. The CHI Navigator includes an easily understandable visual representation of the reasons for working collaboratively with non-health care sectors to improve health (http://www.cdc.gov/chinav/docs/chi_nav_ infographic.pdf), describes hospital-specific examples of successful collaborative interventions, and provides resources and tools to support the process of long-term collaboration and community health improvement. The CHI Navigator guides the user through steps of community action adapted from the University of Wisconsin Population Health Institute County Health Rankings and Roadmaps site (11): 1) assess needs and resources, 2) focus on what is important, 3) choose effective policies and programs, 4) act on what is important, and 5) evaluate actions.

As part of step 3, CDC developed the CHI Navigator database of interventions so that the user can identify evidence-based interventions to address the risk factors for the causes of the most substantial morbidity and mortality in the United States: tobacco use and exposure, physical 
inactivity, unhealthy diet, high cholesterol, high blood pressure, diabetes, and obesity (26). The goal is to assist hospitals and their associated health care organizations and community partners in identifying relevant interventions that they can adapt to have the greatest collective impact on improving their community's health and well-being. Accordingly, the CHI Navigator database of interventions guides hospitals and their affiliated health systems and community partners in identifying multisector collaborative interventions in the four action areas: 1) socioeconomic factors, 2) the physical environment, 3) health behaviors, and 4) clinical care.

\section{Development of the Database of Interventions}

In 2014, CDC convened a team to create the CHI Navigator database of interventions; members included two physicians, four public health researchers and program developers, and later in the process, web designers. This CDC team began by scanning available online resources to identify evidencebased interventions to improve community health (Selection of Source Databases) and established partnerships with organizations that had created sources that would be included in the CHI Navigator database of interventions. Then the team identified multisector collaborative interventions addressing at least one of the causes of greatest morbidity and mortality in the United States, listed previously (Identification of Interventions). Finally, the interventions were organized into categories to help users search for adaptable interventions (Creation of Sorting Filters).

\section{Selection of Source Databases}

The CDC team developed a comprehensive, queriable database of evidence-based interventions that address the following modifiable causes of the greatest morbidity and mortality in the United States: smoking, hypertension, hyperlipidemia, obesity, poor diet, and inactivity (31). Existing databases of interventions were identified that met the following inclusion criteria at the time of development (August 2014): the database had to be free; be accessible online; be navigable using easily accessible, predefined filters or table of contents; be fully developed and complete; provide evidence ratings with clearly defined methods; provide source information and references to the original studies; clearly define outcomes assessed that are related to the conditions of interest; include interventions requiring cross-sector collaboration between two or more sectors (e.g., health care and public health); and include interventions not already covered in other databases in the CHI Navigator (iteratively performed, with The Guide to Community Preventive Services [The Community Guide] as the first database included).

\section{Identification of Interventions}

Selected databases provided two distinct types of entries: 1) summary recommendations based on systematic review or synthesis of current evidence from multiple studies and other evidence-based sources (i.e., reviews) or 2) scientific evaluation of the efficacy of an intervention in a single study (i.e., individual studies). Reviews were defined as reports that provided a summary of a body of evidence that an intervention strategy (or general category of intervention) generally achieved the intended outcomes, whereas individual studies were defined as reports describing a particular intervention that achieved desired outcomes in one or more settings. Individual studies often demonstrated specific examples in greater detail than were outlined in reviews of intervention strategies, or they described approaches that did not yet have the evidence base to warrant a review.

Reviews were drawn from The Community Guide; the American Heart Association (AHA) Guide for Improving Cardiovascular Health at the Community Level, 2013 Update; and the University of Wisconsin County Health Rankings and Roadmaps (CHRR) website, What Works for Health (funded by the Robert Wood Johnson Foundation). Reviews included from source databases met all of the following criteria (Table 1):

1. Review includes systematic reviews or synthesis of strategies tested in more than one study and demonstrating strong or sufficient evidence to suggest a given strategy is beneficial and will likely achieve its intended outcomes.

2. Review is related to one or more modifiable risk factors or social or economic risk factors of interest for the database as described previously.

3. Review describes interdisciplinary, systems-based, or community-based approaches that enhance effectiveness of usual or existing clinical activities.

Duplicate reviews from different source databases were reconciled by using the source that was most recently updated.

Individual studies were identified in the Agency for Healthcare Research and Quality Health Care Innovations Exchange (AHRQ), the Healthy Communities Institute (HCI) database of promising practices, and the New York Academy of Medicine (NYAM) and Trust for America's Health $A$ Compendium of Proven Community-Based Prevention Programs. Interventions included from databases of individual studies met all of the following criteria (Table 1): 
TABLE 1. Characteristics of source databases included in the Community Health Improvement Navigator database of interventions

\begin{tabular}{|c|c|c|c|c|}
\hline Source database & Item type & $\begin{array}{l}\text { Subject terms used to identify } \\
\text { reviews or interventions }\end{array}$ & Level of evidence used for selection & $\begin{array}{l}\text { No. of items } \\
\text { included }\end{array}$ \\
\hline $\begin{array}{l}\text { The Guide to Community Preventive Services (The } \\
\text { Community Guide) } \\
\text { http://www.thecommunityguide.org }\end{array}$ & General reviews & $\begin{array}{l}\text { Cardiovascular disease; } \\
\text { diabetes; nutrition; obesity; } \\
\text { physical activity; social } \\
\text { environment; tobacco }\end{array}$ & $\begin{array}{l}\text { Recommended: Strong or sufficient } \\
\text { evidence to suggest intervention has a } \\
\text { beneficial effect in achieving the intended } \\
\text { outcomes }\end{array}$ & 17 \\
\hline $\begin{array}{l}\text { University of Wisconsin County Health Rankings } \\
\text { and Roadmaps: What Works for Health, funded by } \\
\text { the Robert Wood Johnson Foundation } \\
\text { http://www.countyhealthrankings.org/roadmaps/ } \\
\text { what-works-for-health }\end{array}$ & General reviews & $\begin{array}{l}\text { Tobacco use; diet and exercise } \\
\text { (including high blood pressure, } \\
\text { high cholesterol, obesity, } \\
\text { and diabetes); education; } \\
\text { employment; housing and } \\
\text { transit }\end{array}$ & $\begin{array}{l}\text { Scientifically supported: Most likely to } \\
\text { make a difference; tested in many robust } \\
\text { studies with consistently positive results } \\
\text { Some evidence: Likely to work, but } \\
\text { additional research is needed to confirm } \\
\text { effects; has been tested more than once and } \\
\text { had overall positive results }\end{array}$ & 81 \\
\hline $\begin{array}{l}\text { American Heart Association Guide for Improving } \\
\text { Cardiovascular Health at the Community Level, } \\
2013 \text { Update } \\
\text { http://circ.ahajournals.org/content/127/16/1730 }\end{array}$ & General reviews & $\begin{array}{l}\text { Media and education; } \\
\text { community organization and } \\
\text { partnering; environmental } \\
\text { change; policy change }\end{array}$ & $\begin{array}{l}\text { Systematic reviews, evidence summaries, } \\
\text { and population goals }\end{array}$ & 1 \\
\hline $\begin{array}{l}\text { Agency for Healthcare Research and Quality Health } \\
\text { Care Innovations Exchange } \\
\text { https://www.innovations.ahrq.gov }\end{array}$ & $\begin{array}{l}\text { Example } \\
\text { interventions }\end{array}$ & $\begin{array}{l}\text { Cardiovascular care (including } \\
\text { high blood pressure, high } \\
\text { cholesterol, and physical } \\
\text { inactivity); diet and nutrition } \\
\text { (including obesity); } \\
\text { endocrinologic and metabolic } \\
\text { care (including diabetes); } \\
\text { substance abuse (including } \\
\text { tobacco use and exposure) }\end{array}$ & $\begin{array}{l}\text { Strong: Randomized trial } \\
\text { Moderate: Quasiexperimental design }\end{array}$ & 52 \\
\hline $\begin{array}{l}\text { Healthy Communities Institute database of } \\
\text { promising practices } \\
\text { http://cdc.thehcn.net/index.php?module=promisepr } \\
\text { actice\&controller=index\&action=index }\end{array}$ & $\begin{array}{l}\text { Example } \\
\text { interventions }\end{array}$ & $\begin{array}{l}\text { Type } 2 \text { diabetes; exercise, } \\
\text { nutrition, and weight; heart } \\
\text { disease and stroke; other } \\
\text { chronic diseases; substance } \\
\text { abuse (including tobacco use } \\
\text { and exposure); wellness and } \\
\text { lifestyle }\end{array}$ & $\begin{array}{l}\text { Evidence-based practice: Peer-reviewed, } \\
\text { quantitative evidence of significant positive } \\
\text { impact on prespecified outcomes }\end{array}$ & 62 \\
\hline $\begin{array}{l}\text { New York Academy of Medicine and Trust for } \\
\text { America's Health A Compendium of Proven } \\
\text { Community-Based Prevention Programs } \\
\text { http://healthyamericans.org/assets/files/ } \\
\text { Compendium_Report_1016_1131.pdf }\end{array}$ & $\begin{array}{l}\text { Example } \\
\text { interventions }\end{array}$ & $\begin{array}{l}\text { Reducing the risk of } \\
\text { cardiovascular disease, stroke } \\
\text { and diabetes (including } \\
\text { high blood pressure, high } \\
\text { cholesterol, physical inactivity } \\
\text { and unhealthy diet); reducing } \\
\text { tobacco use }\end{array}$ & $\begin{array}{l}\text { Rigorous evaluation: With a minimum } \\
\text { standard set of information (e.g., the } \\
\text { intervention population, setting, the cost } \\
\text { of the intervention, and the duration } \\
\text { of the intervention); preference for } \\
\text { examples effective in communities with } \\
\text { disproportionate levels of disease }\end{array}$ & 36 \\
\hline
\end{tabular}

1. Intervention meets minimal evidence rating of at least one study or evaluation of the intervention using an experimental or quasiexperimental design.

2. Intervention is related to one or more modifiable risk factors of interest for the database.

3. Intervention describes interdisciplinary, systems-based, or community-based approaches that enhance clinical activities.

4. Intervention is not considered direct, usual clinical care.

Duplicates among individual studies gathered from different source databases were reconciled by using the source with the most detailed online content about the study.

Because one criterion was to include reviews and individual studies of interventions that were evidence based, only items from The Community Guide with a rating of recommended were included, and only those from CHRR with that were either scientifically supported or had some evidence of effectiveness were included. For sources of individual studies, only those that were evaluated using at least a quasiexperimental design were included. This restricted items to those rated as strong or moderate for AHRQ or evidence based for HCI. All items included in NYAM and AHA met the minimal evidence threshold criteria (Table 1).

\section{Creation of Sorting Filters}

The CDC team then tagged all reviews and interventions that met inclusion criteria with descriptors so that they could be sorted into useful categories. The goal of the CHI Navigator database of interventions is to encourage users to create multisector coalitions and identify interventions on the basis of needs and existing assets of their community to 
improve community health. As such, CDC used a participatory process that engaged stakeholders likely to use this resource to develop a categorization scheme to allow the user to easily sort the included reviews and individual studies by these criteria.

The CDC team developed a preliminary list of sorting filters that was developed on the basis of existing filters used in the source databases (Table 1). Specific filters were used to identify human and organizational assets within different community sectors (e.g., residents and community health workers, local businesses and nonprofits, and clinicians and health care workers) to encourage creation of multisector coalitions and heighten recognition of the role non-health care partners can play. This preliminary list was then circulated among various stakeholders and potential users, and the list was revised based on their feedback. (A list of persons who provided feedback is available at http://stacks.cdc.gov/view/ cdc/37770; in addition, a database of Community Health Needs Assessment collaboration resource contacts is available at http://stacks.cdc.gov/view/cdc/37771.) All reviews and individual studies were tagged with all applicable filters. All individual studies also were linked to related reviews that they exemplified. For example, an individual study called Activity Bursts in the Classroom was tagged with the following filters: physical inactivity, obesity, children/adolescents, physical activity, school, and local institutions. The team also tagged this individual study to the review summarizing the evidence on physically active classrooms.

A validation team of two CDC public health program developers not included in the initial designation process reviewed all assignments. The entire group then discussed and clarified all discrepancies found by the validation team until consensus for inclusion and exclusion of each filter designation was reached for each review and individual study.

\section{Results}

\section{Source Databases}

A total of 13 potential source databases were considered for inclusion in the CHI Navigator database of interventions. Using the criteria described, six database sources were selected (Table 1). Three of these sources provided synthesized reviews (TCG, CHRR, and AHA), and three sources provided detailed information on specific individual studies (AHRQ, HCI, and NYAM).

\section{Interventions}

From all six sources, 99 unique reviews and 150 individual studies met all inclusion criteria. The most reviews were from
CHRR $(\mathrm{N}=81)$. A total of 52 individual studies were obtained from AHRQ, 62 from HCI, and 36 from NYAM.

A total of 72 reviews and individual studies addressed risk factors such as tobacco use and exposure, 113 physical inactivity, 110 unhealthy diet, 17 high cholesterol, 57 high blood pressure, 60 diabetes, and 86 obesity (Table 2). Interventions could have been associated with multiple risk factor filters because risk factors are not mutually exclusive.

\section{Sorting Filters}

A list of 64 filters was created to help the user search for interventions that address the risk factors of interest within similar communities using comparable multisector collaborations. The final set of filters was organized into the following categories: 1) risk factors, 2) populations, 3) outcomes or indicators, 4) intervention setting or location, 5) intervention types, 6) assets: persons or organizations, and 6) assets: physical or virtual space (Box). The online $\mathrm{CHI}$ Navigator includes a glossary that defines the four action areas, the filter categories, and each of the filters. These filters help the user identify adaptable interventions relevant to the needs of their community.

In the database of interventions, users can select the highest priority risk factors for their community. They are then able to select as many filters within each category as applicable. The search results include reviews and individual studies that relate to any of the selected filters within a category, and, if filters also were selected from another category, results include reviews and studies that relate to at least one of the filters identified in each additional category. Users can match both strategy and individual intervention with the needs, preferences, and resources of their community.

\section{Hypothetical Example}

Following is a hypothetical example of how the CHI Navigator database of interventions might be used (Table 3). A hospital partners with the local health department to perform a community health needs assessment. They determine that the prevalence of hypertension and obesity in their community is higher than the national average and that blacks have 50\% higher prevalence of hypertension than other races/ethnicities. The health department informs the hospital that local churches are interested in addressing hypertension in the community and have begun community blood pressure screenings sponsored by a local insurer. The hospital also is aware that some local employers are interested improving employees' health behaviors and decreasing their health care costs.

The hospital organizes a meeting with leaders from the health department, faith-based organizations, community members, 
TABLE 2. Number of reviews and individual studies included in each risk factor category for the Community Health Improvement Navigator database of interventions

\begin{tabular}{|c|c|c|c|c|c|c|c|}
\hline Source & $\begin{array}{c}\text { Tobacco use and } \\
\text { exposure }\end{array}$ & $\begin{array}{l}\text { Physical } \\
\text { inactivity }\end{array}$ & $\begin{array}{c}\text { Unhealthy } \\
\text { diet }\end{array}$ & $\begin{array}{c}\text { High } \\
\text { cholesterol }\end{array}$ & $\begin{array}{l}\text { High blood } \\
\text { pressure }\end{array}$ & Diabetes & Obesity \\
\hline TCG & 10 & 6 & 6 & 3 & 9 & 10 & 6 \\
\hline RWJF CHRR & 27 & 39 & 39 & 1 & 18 & 12 & 27 \\
\hline $\mathrm{AHA}$ & 0 & 0 & 0 & 0 & 1 & 0 & 0 \\
\hline AHRQ & 4 & 20 & 21 & 4 & 16 & 21 & 21 \\
\hline $\mathrm{HCl}$ & 10 & 39 & 40 & 4 & 8 & 13 & 26 \\
\hline NYAM TFAH & 21 & 9 & 4 & 5 & 5 & 4 & 6 \\
\hline
\end{tabular}

Abbreviations: AHA = American Heart Association Guide for Improving Cardiovascular Health at the Community Level, 2013 Update; AHRQ = Agency for Healthcare Research and Quality Health Care Innovations Exchange; $\mathrm{HCl}=$ Healthy Communities Institute database of promising practices; NYAM TFAH = New York Academy of Medicine and Trust for America's Health Compendium of Proven Community-Based Prevention Programs; RWJF CHRR=University of Wisconsin County Health Rankings \& Roadmaps, funded by the Robert Wood Johnson Foundation; TCG = The Guide to Community Preventive Services (The Community Guide).

\section{BOX. Filters available in the Community Health Improvement Navigator database of interventions}

\begin{tabular}{|c|c|c|}
\hline $\begin{array}{l}\text { Risk factor } \\
\text { Tobacco use and exposure } \\
\text { High cholesterol } \\
\text { High blood pressure } \\
\text { Diabetes } \\
\text { Obesity } \\
\text { Population } \\
\text { Racial/ethnic minorities } \\
\text { Low-income populations } \\
\text { Children/adolescents } \\
\text { Families } \\
\text { Adults } \\
\text { Older adults } \\
\text { Men } \\
\text { Women } \\
\text { Urban } \\
\text { Rural } \\
\text { Outcome or indicator } \\
\text { Tobacco use and exposure } \\
\text { Physical activity } \\
\text { Healthy food/beverage intake } \\
\text { Cholesterol/lipid level } \\
\text { Blood pressure } \\
\text { Hemoglobin a1c/glycemic control } \\
\text { Body mass index/weight } \\
\text { Health care costs } \\
\text { Mortality } \\
\text { Treatment adherence }\end{array}$ & $\begin{array}{l}\text { Intervention setting or location } \\
\text { Business/worksite } \\
\text { School } \\
\text { Child care facility } \\
\text { Faith-based setting } \\
\text { Community } \\
\text { Pharmacy } \\
\text { Clinic } \\
\text { Hospital } \\
\text { Telehealth } \\
\text { Intervention type } \\
\text { Access to care } \\
\text { Counseling } \\
\text { Education } \\
\text { Program } \\
\text { Point-of-decision prompt } \\
\text { Financial incentive/offset costs } \\
\text { Healthy food/beverage provision } \\
\text { Campaigns } \\
\text { Media/marketing } \\
\text { Changing physical environment } \\
\text { Policy }\end{array}$ & $\begin{array}{l}\text { Assets: persons or organizations } \\
\text { Residents/community health workers } \\
\text { Hospitals/clinicians/health care workers } \\
\text { Payers/insurers } \\
\text { Health department/public health officials } \\
\text { Policymakers/local council members } \\
\text { Local businesses/nonprofit organizations } \\
\text { Voluntary associations } \\
\text { Researchers/evaluators } \\
\text { Assets: physical or virtual space } \\
\text { Local institutions } \\
\text { Parks/community common space } \\
\text { Website/community listserv } \\
\text { Local media: radio/television/print } \\
\text { Transportation } \\
\text { Housing development/urban planning }\end{array}$ \\
\hline
\end{tabular}

local businesses, and insurance organizations. Together, they decide to address hypertension in their community. They go to the online database of interventions and select high blood pressure as the risk factor, racial/ethnic minorities as the population, and faith-based setting as the intervention setting. The human and organizational assets are the health department and public health officials; hospitals, clinicians, and health care workers; local businesses and nonprofit organizations; payers and insurers; and residents and community health workers. Results include reviews and individual studies that address hypertension in similar populations designed or implemented by any of the human or organizational assets selected. Users from the hospital match both strategy and individual interventions with the needs, preferences, and resources of their community.

\section{Discussion}

The CHI Navigator was developed to assist hospitals in meeting new IRS regulations and to facilitate identification of evidence-informed multisector collaborative interventions to improve the health and well-being of communities. The tool includes a database of interventions that includes results from six different resources, and the content is aggregated into one website that is searchable using filters that highlight multisector collaboration and community assets. Although initially focused on seven health risk factors related to the most common causes of morbidity and mortality in the United States, the methods and design are adaptable and can be expanded to incorporate other important community health issues (e.g., 
Supplement

TABLE 3. Recommended steps for use of the Community Health Improvement Navigator by health care systems and community collaborators, with a hypothetical example

\begin{tabular}{|c|c|}
\hline Recommended step & Example \\
\hline $\begin{array}{l}\text { Step 1: Establish a cross-sector coalition with the goal of } \\
\text { improving community health. }\end{array}$ & $\begin{array}{l}\text { Included members are an academic hospital, two local businesses, a local health department, a } \\
\text { private insurer, two faith-based organizations, and a community action team. }\end{array}$ \\
\hline Step 2: Identify greatest health need. & Hypertension \\
\hline Step 3: Identify disparities in the community. & $\begin{array}{l}\text { Blacks have a higher prevalence of uncontrolled hypertension than other races/ethnicities in this } \\
\text { community. }\end{array}$ \\
\hline Step 4: Select filters in the database. & $\begin{array}{l}\text { - High blood pressure } \\
\text { - Racial/ethnic minorities } \\
\text { - Faith-based setting } \\
\text { - Residents and community health workers; health department and public health officials; } \\
\text { hospitals, clinicians, and health care workers; local businesses and nonprofit organizations; and } \\
\text { payers and insurers }\end{array}$ \\
\hline $\begin{array}{l}\text { Step 5: Choose a general strategy and the most applicable } \\
\text { intervention. }\end{array}$ & $\begin{array}{l}\text { Three reviews are returned with four example interventions. The coalition discusses these and } \\
\text { adapts an intervention that best suits their community with a plan to monitor and evaluate } \\
\text { outcomes on hypertension. }\end{array}$ \\
\hline
\end{tabular}

mental health, sexually transmitted infections, and teen pregnancy). In addition, the conceptual model underscores the four modifiable action areas that affect a broad range of preventable health outcomes (e.g., socioeconomic factors, physical environment, health behaviors, and clinical care) (12).

The database of interventions includes evidence-based interventions within these action areas that align with ongoing national health promotion initiatives, required reporting mechanisms, and the new IRS requirements for tax exempt status for hospitals. The database of interventions includes interventions shown to reduce blood pressure, lipid levels, blood glucose levels, and smoking rates, which are preventive measures supported by the Million Hearts initiative, Healthy People 2020 national health objectives, and the National Prevention Strategy (32-34). Many of the outcomes also are measures included in publicly reported databases, such as the Physician Quality Reporting System, making the CHI Navigator framework and included interventions salient for health systems. This tool might help tax-exempt hospitals and their associated health care systems to meet the new IRS requirements and fulfill their public mission to improve community health.

\section{Limitations}

The findings in this report are subject to at least three limitations, all of which are related to the limitations of the available published studies used to create the database. First, the interventions that were included in previously constructed sources were aggregated, and the information provided by these sources was assumed reliable. Included reviews and interventions were linked to source documentation and peer-reviewed manuscripts, and partnerships were developed with source database developers to ensure hyperlinks and information remain as up to date as possible. Second, although many interventions examine expansion of clinical care services and programs to improve health behaviors, few report information on cost or data on policy interventions, perhaps because they have not been studied or results have not been published. Therefore, information about the expected return on investment of each intervention could not be provided. Finally, few socioeconomic interventions reported health impact data, and few data were available on the impact of interventions working simultaneously within multiple domains. Therefore, findings had to be extrapolated from other studies examining the general impact of socioeconomic factors on health (e.g., the impact of achieving a high school education on obesity rate) to estimate the expected health impact of socioeconomic interventions included in the CHI Navigator database.

\section{Conclusion}

Although the limitations of the studies included in the CHI Navigator database of interventions reflect the limitations of the available evidence, they highlight the need for more research and evaluation of collaborative interventions addressing multiple determinants of health. The database of interventions is embedded within a larger tool that describes the benefits of a collaborative approach to community health improvement and a process to achieve this goal. The interventions included in the CHI Navigator database of interventions involve collaboration, addressing community health by focusing simultaneously on multiple determinants of health (i.e., the action areas) via cross-sector partnerships. Collaborative approaches can substantially improve the health 
and well-being of the population while reducing disparities in health outcomes (18). The database might encourage the creation of more cross-sector community coalitions, which could improve community health and encourage future research to evaluate the effectiveness of resulting programs. Prospective, shared data are needed to monitor improvement and impact.

CDC plans to expand the current $\mathrm{CHI}$ Navigator database of interventions to include additional source databases and other health indicators. Together with the other CHI Navigator components, the database of interventions has the potential to encourage and inspire communities to take action that will improve the health of their communities.

\section{References}

1. Bradley E, Taylor L. The American health care paradox: why spending more is getting us less. New York, NY: Public Affairs; 2013.

2. Bradley EH, Elkins BR, Herrin J, Elbel B. Health and social services expenditures: associations with health outcomes. BMJ Qual Saf 2011;20:826-31. http://dx.doi.org/10.1136/bmjqs.2010.048363.

3. Organisation for Economic Co-operation and Development. Health at a glance 2013: OECD indicators. Paris, France: Organisation for Economic Co-operation and Development; 2013. http://www.oecd.org/ els/health-systems/Health-at-a-Glance-2013.pdf.

4. Davis K, Schoen C, Stremikis K. Mirror, mirror on the wall: how the performance of the U.S. health care system compares internationally, 2010 update. New York, NY: The Commonwealth Fund; 2012. http:// www.commonwealthfund.org/ $/$ media/Files/Publications/Fund $\% 20$ Report/2010/Jun/1400_Davis_Mirror_Mirror_on_the_wall_2010.pdf.

5. Shaw FE, Asomugha CN, Conway PH, Rein AS. The Patient Protection and Affordable Care Act: opportunities for prevention and public health. Lancet 2014;384:75-82. http://dx.doi.org/10.1016/S0140-6736 (14)60259-2.

6. Kassler WJ, Tomoyasu N, Conway PH. Beyond a traditional payerCMS's role in improving population health. N Engl J Med 2015;372:109-11. http://dx.doi.org/10.1056/NEJMp1406838.

7. Wernham A, Teutsch SM. Health in all policies for big cities. J Public Health Manag Pract 2015;21(Suppl 1):S56-65. http://dx.doi. org/10.1097/PHH.0000000000000130.

8. Thorpe KE. Factors accounting for the rise in health-care spending in the United States: the role of rising disease prevalence and treatment intensity. Public Health 2006;120:1002-7. http://dx.doi.org/10.1016/j. puhe.2006.09.001.

9. CDC. Indicators for chronic disease surveillance. MMWR Recomm Rep 2004;53(No. RR-11).

10. Frieden TR. A framework for public health action: the health impact pyramid. Am J Public Health 2010;100:590-5. http://dx.doi. org/10.2105/AJPH.2009.185652.

11. University of Wisconsin Population Health Institute, Robert Wood Johnson Foundation. County health rankings and roadmaps. Madison, WI: University of Wisconsin Population Health Institute; 2014. http:// www.countyhealthrankings.org/our-approach.

12. McGinnis JM, Williams-Russo P, Knickman JR. The case for more active policy attention to health promotion. Health Aff (Millwood) 2002;21:78-93. http://dx.doi.org/10.1377/hlthaff.21.2.78.

13. Campbell F, Conti G, Heckman JJ, et al. Early childhood investments substantially boost adult health. Science 2014;343:1478-85. http:// dx.doi.org/10.1126/science.1248429.
14. Ross CE, Mirowsky J. The interaction of personal and parental education on health. Soc Sci Med 2011;72:591-9. http://dx.doi.org/10.1016/j. socscimed.2010.11.028.

15. Giles-Corti B, Donovan RJ. The relative influence of individual, social and physical environment determinants of physical activity. Soc Sci Med 2002;54:1793-812. http://dx.doi.org/10.1016/S0277-9536(01)00150-2.

16. Peek ME, Ferguson M, Bergeron N, Maltby D, Chin MH. Integrated community-healthcare diabetes interventions to reduce disparities. Curr Diab Rep 2014;14:467. http://dx.doi.org/10.1007/s11892-013-0467-8.

17. Betancourt JR, Duong JV, Bondaryk MR. Strategies to reduce diabetes disparities: an update. Curr Diab Rep 2012;12:762-8. http://dx.doi. org/10.1007/s11892-012-0324-1.

18. Barnett K, Rosenbaum S. Community health assessments: past, present, and future. In: Michener JL, Koo D, Castrucci BC, Sprague JB, eds. The practical playbook. Public health and primary care together. New York, NY: Oxford University Press; 2016;167-79.

19. Balk EM, Earley A, Raman G, Avendano EA, Pittas AG, Remington PL. Combined diet and physical activity promotion programs to prevent type 2 diabetes among persons at increased risk: a systematic review for the Community Preventive Services Task Force. Ann Intern Med 2015;163:437-51. http://dx.doi.org/10.7326/M15-0452.

20. Li R, Qu S, Zhang P, et al. Economic evaluation of combined diet and physical activity promotion programs to prevent type 2 diabetes among persons at increased risk: a systematic review for the Community Preventive Services Task Force. Ann Intern Med 2015;163:452-60. http://dx.doi.org/10.7326/M15-0469.

21. Pronk NP, Remington PL; Community Preventive Services Task Force. Combined diet and physical activity promotion programs for prevention of diabetes: Community Preventive Services Task Force recommendation statement. Ann Intern Med 2015;163:465-8. http://dx.doi.org/10.7326/ M15-1029.

22. Taylor LA, Coyle CE, Ndumele C, et al. Leveraging the social determinants of health. What works? New Haven, CT: Blue Cross and Blue Shield of Massachusetts Foundation, Yale Global Health Leadership Institute; 2015. http://www.socialserviceworkforce.org/system/files/ resource/files/Social_Equity_Report_Final.pdf.

23. Record NB, Onion DK, Prior RE, et al. Community-wide cardiovascular disease prevention programs and health outcomes in a rural county, 1970-2010. JAMA 2015;313:147-55. http://dx.doi.org/10.1001/ jama.2014.16969.

24. CDC. Best practices for community health needs assessment and implementation strategy development: a review of scientific methods, current practices, and future potential. Report of proceedings from a public form and interviews of experts [Forum]. Atlanta, GA: CDC, US Department of Health and Human Services; 2012. http://www.cdc.gov/ policy/ohsc/chna.

25. Additional Requirements for Charitable Hospitals; Community Health Needs Assessments for Charitable Hospitals; Requirement of a Section 4959 Excise Tax Return and Time for Filing the Return. 26 C.F.R. Parts 1, 53, and 602. (2014).

26. Burwell SM. Setting value-based payment goals-HHS efforts to improve U.S. health care. N Engl J Med 2015;372:897-9. http://dx.doi. org/10.1056/NEJMp1500445.

27. Khan LK, Sobush K, Keener D, et al. Recommended community strategies and measurements to prevent obesity in the United States. MMWR Recomm Rep 2009;58(No. RR-7).

28. Chillón P, Evenson KR, Vaughn A, Ward DS. A systematic review of interventions for promoting active transportation to school. Int J Behav Nutr Phys Act 2011;8:10. http://dx.doi.org/10.1186/1479-5868-8-10.

29. Turner L, Chriqui JF, Chaloupka FJ. Walking school bus programs in U.S. public elementary schools. J Phys Act Health 2013;10:641-5.

30. Mendoza JA, Watson K, Nguyen N, Cerin E, Baranowski T, Nicklas TA. Active commuting to school and association with physical activity and adiposity among U.S. youth. J Phys Act Health 2011;8:488-95. 
31. Mokdad AH, Marks JS, Stroup DF, Gerberding JL. Actual causes of death in the United States, 2000. JAMA 2004;291:1238-45. http:// dx.doi.org/10.1001/jama.291.10.1238.

32. CDC. Million hearts. Atlanta, GA: US Department of Health and Human Services, CDC; 2015. http://millionhearts.hhs.gov.
33. CDC. Healthy people 2020. Atlanta, GA: US Department of Health and Human Services, CDC; 2016. http://www.healthypeople.gov.

34. Office of the Surgeon General. National prevention strategy. Washington, DC: US Department of Health and Human Services, Office of the Surgeon General; 2011. http://www.surgeongeneral.gov/priorities/ prevention/strategy. 
The Morbidity and Mortality Weekly Report (MMWR) Series is prepared by the Centers for Disease Control and Prevention (CDC) and is available free of charge in electronic format. To receive an electronic copy each week, visit MMWR's free subscription page at http://www.cdc.gov/mmwr/mmwrsubscribe.html. Paper copy subscriptions are available through the Superintendent of Documents, U.S. Government Printing Office, Washington, DC 20402; telephone 202-512-1800.

Readers who have difficulty accessing this PDF file may access the HTML file at http://www.cdc.gov/mmwr/volumes/65/su/su6502a1.htm?s_ cid=su6502a1_w. Address all inquiries about the $M M W R$ Series, including material to be considered for publication, to Executive Editor, $M M W R$ Series, Mailstop E-90, CDC, 1600 Clifton Rd., N.E., Atlanta, GA 30329-4027 or to mmwrq@cdc.gov.

All material in the MMWR Series is in the public domain and may be used and reprinted without permission; citation as to source, however, is appreciated. Use of trade names and commercial sources is for identification only and does not imply endorsement by the U.S. Department of Health and Human Services.

References to non-CDC sites on the Internet are provided as a service to $M M W R$ readers and do not constitute or imply endorsement of these organizations or their programs by CDC or the U.S. Department of Health and Human Services. CDC is not responsible for the content of these sites. URL addresses listed in $M M W R$ were current as of the date of publication.

ISSN: 2380-8950 (Print) 